\title{
Efek ekstrak teh hijau (Camellia sinensis (L.) O. Kuntze var. assamica) terhadap berat badan dan kadar malondialdehid wanita overweight
}

\author{
Effect of green tea (Camellia sinensis (L.) O. Kuntze var. assamica) extract supplementation on weight and \\ malondialdehid level of overweight women
}

Alpha Olivia Hidayati ${ }^{1}$, Wiryatun Lestariana ${ }^{2}$, Emy Huriyati ${ }^{3}$

\begin{abstract}
Background: Overweight and obesity were risk factors of various degenerative diseases. Green tea extract contains polyphenol compounds, particularly catechins which act as antioxidants, fat dissolvent and aid lipolysis. Thus, it is necessary to study the use of green tea as an alternative treatment to overcome overweight.

Objective: To identify the effect of green tea extract supplementation on body weight and malondialdehide (MDA) level of overweight women in Yogyakarta District Health Office.

Method: This was an experimental study with double-blind randomized controlled trial design. Subject of the study were divided into two groups; one group consumed green tea extract capsules and the other consumed placebo. Weight, 6 times 24 hours recall, and level of MDA were measured on every subject.

Result: The results revealed that green tea extract has a weight-reducing effect and decrease MDA level of overweight women, though the reduction of weight and MDA level was not significant $(p>0,05)$. Weight loss of $1.3 \%$ was observed in the treatment group, whereas the control group has an increase of $0.6 \%$ body weight, but the weight change was not significant $(p=0.501, p=0.620)$. Changes in body weight after 12 weeks of treatment showed a significant disparity between the two groups $(p=0.000)$. MDA level decreased by $10 \%$ in the treatment group compared to $8.3 \%$ in the control group. MDA levels pre and post intervention was significantly different in the treatment group $(p=0.006)$, whereas in the control group there was no significant discrepancy observed $(p=0.123)$. However, changes in MDA levels after 12 weeks of treatment showed no significant differences among groups $(p=0.278)$. The mean nutrient intakes of subjects were still below the recommended dietary allowance (RDA), except for protein.

Conclusion: Green tea extract had a weight-reducing effect and decrease MDA level of overweight women in Yogyakarta District Health Office, though the reduction was not statistically significant.
\end{abstract}

KEY WORDS: green tea extract, overweight, body weight, malondialdehid

\begin{abstract}
ABSTRAK
Latar belakang: Kegemukan (overweight) mempunyai kecenderungan lebih besar untuk menjadi obesitas di kemudian hari. Obesitas merupakan faktor risiko terjadinya penyakit degeneratif yang berdampak pada kematian. Ekstrak teh hijau mengandung polifenol berupa katekin yang berfungsi sebagai antioksidan, pembakar lemak, dan lipolisis. Oleh karena itu, perlu dilakukan penelitian mengenai penanganan overweight dengan menggunakan ekstrak teh hijau.

Tujuan: Untuk mengkaji pengaruh pemberian ekstrak teh hijau terhadap penurunan berat badan dan kadar malondialdehid (MDA) wanita dewasa overweight di lingkungan pegawai Dinas Kesehatan Kota Yogyakarta.

Metode: Jenis penelitian ini adalah eksperimental dengan rancangan Randomized Controlled Trial (RCT) dengan double blinded selama 90 hari. Subjek penelitian dibagi dua kelompok, kelompok pertama mengonsumsi kapsul ekstrak teh hijau dan kelompok kedua mengonsumsi kapsul plasebo. Pengukuran berat badan, recall 24 jam sebanyak 6 kali, dan pengukuran kadar MDA dilakukan pada setiap subjek penelitian.

Hasil: Hasil penelitian menunjukkan bahwa pemberian ekstrak teh hijau dapat menurunkan berat badan dan kadar MDA wanita dewasa overweight di lingkungan pegawai Dinas Kesehatan Kota Yogyakarta namun penurunan tersebut tidak signifikan ( $p>0,05)$. Terjadi penurunan berat badan sebesar 1,3\% pada kelompok perlakukan sedangkan pada kelompok kontrol terjadi kenaikan berat badan sebesar $0,6 \%$, namun keduanya tidak signifikan $(p=0,501 ; p=0,620)$. Perubahan berat badan selama 12 minggu menunjukkan perbedaan yang signifikan $(p>0,05)$ antara kelompok perlakuan dan kelompok kontrol $(p=0,000)$. Kadar MDA menurun sebesar $10 \%$ pada kelompok perlakuan dan $8,3 \%$ pada kelompok kontrol. Pada kelompok perlakuan terdapat perbedaan yang signifikan antara kadar MDA awal dan akhir penelitian $(p=0,006)$, tidak demikian dengan kelompok kontrol $(p=0,123)$. Perubahan kadar MDA selama 12 minggu menunjukkan perbedaan yang tidak signifikan antara kelompok kontrol dan perlakuan $(p=0,278)$. Rerata asupan zat gizi subjek masih di bawah nilai angka kecukupan gizi (AKG) kecuali protein.
\end{abstract}

\footnotetext{
${ }^{1}$ Korepondensi: Politeknik Muhammadiyah Yogyakarta, Jl. Lingkar Selatan, Kasihan, Bantul, Yogyakarta, e-mail: azkiya_alph@yahoo.co.id

${ }^{2}$ Bagian Biokimia, Fakultas Kedokteran Universitas Gadjah Mada, Jl. Farmako, Sekip Utara, Yogyakarta 55281

${ }^{3}$ Program Studi Gizi Kesehatan, Fakultas Kedokteran Universitas Gadjah Mada, Jl. Farmako, Sekip Utara, Yogyakarta 55281
} 

Kesimpulan: Pemberian ekstrak teh hijau dapat menurunkan berat badan dan kadar MDA wanita dewasa overweight
di lingkungan pegawai Dinas Kesehatan Kota Yogyakarta namun penurunan tersebut tidak signifikan.

KATA KUNCI: ekstrak teh hijau, overweight, berat badan, MDA

\section{PENDAHULUAN}

Kegemukan (overweight) cenderung berdampak lebih besar untuk menjadi obesitas di kemudian hari. Obesitas sudah menjadi masalah kesehatan di Indonesia. Obesitas merupakan faktor risiko terjadinya penyakit degeneratif antara lain kardiovaskuler, aterosklerosis, kanker, diabetes mellitus, dan hipertensi (1). Berdasarkan data riset kesehatan dasar (Riskesdas) tahun 2010, prevalensi nasional obesitas pada penduduk berusia lebih dari 18 tahun adalah $21,7 \%$ dengan prevalensi pada lakilaki $16,3 \%$ dan perempuan $26,9 \%$ (2).

Faktor-faktor pencetus overweight meliputi faktor genetik, lingkungan (aktivitas fisik, psikologis, sosial ekonomi, dan kebiasaan makan), umur, dan jenis kelamin (3). Overweight ditandai dengan proporsi berat badan terhadap tinggi badan yang tidak seimbang. Kebiasaan konsumsi makanan yang tidak sehat juga memberikan dampak penumpukan radikal bebas di dalam tubuh. Tingginya kadar radikal bebas terlihat dari rendahnya aktivitas antioksidan dan tingginya kadar malondialdehid (MDA) dalam darah. Kondisi ini berakibat pada terjadinya kerusakan jaringan, penyakit autoimun, penyakit degeneratif, dan kanker. Oleh karena itu, tubuh membutuhkan perlindungan dari reaktivitas radikal bebas dengan antioksidan yang dapat diperoleh dari teh (1).

Di Indonesia, teh hitam lebih banyak dikonsumsi dibandingkan teh hijau. Padahal sebetulnya teh hijau mempunyai khasiat lebih baik untuk kesehatan dan kecantikan karena teh hijau tidak mengalami proses fermentasi sehingga zat kimia teh masih utuh terutama kadar polifenolnya (4). Tanaman teh yang tumbuh di Indonesia sebagian besar merupakan varietas assamica. Teh varietas assamica mempunyai kelebihan dalam hal kandungan katekin yang lebih tinggi (5).

Teh hijau (Camelia sinensis (L.) O. Kuntze) var. assamica mengandung polifenol, flavonoid, dan tanin. Polifenol dalam teh hijau dikenal sebagai katekin. Dibandingkan dengan jenis teh lain seperti teh hitam dan teh oolong maka kandungan polifenol pada teh hijau jauh lebih tinggi walaupun berasal dari pohon yang sama (6). Teh hijau mengandung 10 - 50\% katekin berupa epigalocatechin gallat (EGCG) yang merupakan sumber dari sebagian besar manfaat positif daun teh (7). Selain itu, teh hijau memiliki toksisitas yang rendah (8). Berbagai penelitian menunjukkan teh hijau bermanfaat untuk mencegah kanker, osteoporosis, penyakit kardiovaskuler, dan aterosklerosis. Sementara itu, untuk perawatan kecantikan, teh hijau berperan sebagai antioksidan, menghilangkan bau mulut, mencegah karies gigi, dan meningkatkan pembakaran lemak (4, 9-13). Beberapa penelitian tentang efek pemberian ekstrak teh hijau terhadap penurunan berat badan telah dilakukan, namun penelitian-penelitian tersebut baru dapat membuktikan adanya efek penurunan berat badan pada pria dan binatang (tikus). Penelitian ini belum pernah dilakukan pada wanita padahal kasus overweight di Indonesia lebih banyak dialami oleh wanita (2). Penelitian membuktikan bahwa konsumsi ekstrak teh hijau menyebabkan penurunan berat badan yang signifikan pada tikus galur Wistar (5). Penelitian lain juga dilakukan di Netherlands (10) dan Tokyo (12), kedua penelitian tersebut menunjukkan adanya penurunan berat badan pada pria yang diberikan ekstrak teh hijau. Demikian pula dengan efek konsumsi ekstrak teh hijau terhadap kadar MDA yang dilakukan pada hewan coba (tikus). Hasil penelitian tersebut menunjukkan adanya penurunan kadar MDA pada tikus yang mengonsumsi ekstrak teh hijau (14).

Dinas Kesehatan Kota Yogyakarta memiliki 732 orang pegawai yang tersebar di 18 puskesmas Kota Yogyakarta dan dinas kesehatan, terdiri dari 216 laki-laki dan 516 wanita yang separuh wanita diantaranya termasuk overweight dan obesitas. Sementara itu, pegawai dinas kesehatan berada di baris depan dalam bidang kesehatan sebagai contoh pelaksanaan program pemerintah. Penelitian ini bertujuan untuk mengetahui efek pemberian ekstrak teh hijau (Camelia sinensis (L.) O. Kuntze) var. assamica terhadap berat badan dan kadar MDA wanita dewasa overweight di lingkungan pegawai Dinas Kesehatan Kota Yogyakarta.

\section{BAHAN DAN METODE}

Penelitian ini merupakan penelitian eksperimental dengan rancangan penelitian randomized controlled trial (RCT) dan double blind yang artinya baik peneliti, enumerator maupun subjek penelitian tidak mengetahui pembagian anggota kelompok kontrol maupun perlakuan. Penentuan kelompok kontrol dan kelompok perlakuan hanya diketahui oleh apoteker yang bertugas mempersiapkan kapsul dengan kode A dan kode B yang akan diberikan kepada subjek penelitian. Apoteker merupakan orang di luar penelitian yang tidak terlibat langsung dalam penelitian. Penelitian ini dilaksanakan pada bulan Maret-Juli 2010 di lingkungan Dinas Kesehatan Kota Yogyakarta khususnya 16 puskesmas di Kota Yogyakarta yang memenuhi kriteria yaitu bersedia menjadi tempat penelitian. Penelitian ini telah memperoleh ethical clearance dari Komisi Etik Penelitian Kedokteran dan Kesehatan Fakultas Kedokteran Universitas Gadjah Mada. 
Populasi penelitian adalah wanita usia 35-55 tahun yang bekerja di lingkungan Dinas Kesehatan Kota Yogyakarta karena pada umur tersebut prevalensi obesitas cenderung meningkat (2). Besar sampel penelitian diperoleh dengan menggunakan perhitungan rumus beda rata-rata dua populasi (15) dengan tingkat kepercayaan 95\%; power $90 \%$; perbedaan rata-rata berat badan dan indeks massa tubuh (IMT) antara kelompok kontrol dan perlakuan $(\mu 1-\mu 2)$ sebesar 1,1 ; dan standar deviasi sebesar 1,3 (12). Berdasarkan perhitungan jumlah sampel di atas maka jumlah sampel minimal sebesar 30 orang untuk setiap kelompok, namun untuk mengantisipasi sampel yang luput dari pengamatan (drop out) maka jumlah sampel ditambah sebesar $10 \%$ sehingga jumlah sampel yang diperlukan adalah 33 orang untuk setiap kelompok. Pengambilan sampel dengan menggunakan teknik random sampling.

Kriteria inklusi subjek penelitian yaitu wanita usia 35-55 tahun dengan overweight berdasarkan IMT penduduk Asia dewasa menurut World Health Organization (WHO) yaitu $23-27,5 \mathrm{~kg} / \mathrm{m}^{2}(16)$, bersedia mengikuti penelitian dan menandatangani informed consent, tidak sedang mengonsumsi obat-obatan diit sekurangnya 2 minggu sebelum penelitian, dan tidak sedang menjalani program diit. Kriteria eksklusinya yaitu instruktur senam atau atlet, merokok dan mengonsumsi alkohol, sudah mengonsumsi teh hijau atau ekstrak teh hijau secara rutin sebelum penelitian, ibu hamil dan menyusui, mempunyai penyakit jantung, diabetes mellitus, hipertensi, dan ginjal. Berdasarkan kriteria di atas diperoleh 87 subjek penelitian.

Jenis intervensi dirandomisasi pada tingkat individu dengan alokasi rasio $1: 1$. Kelompok $A$ mengonsumsi kapsul dengan kode A sebanyak 1 kali sehari selama 90 hari sedangkan kelompok $B$ mengonsumsi kapsul dengan kode B sebanyak 1 kali sehari selama 90 hari. Observasi dilakukan pada kedua kelompok pada awal intervensi serta pada hari ke-30, ke-60, dan ke-90. Berdasarkan hasil randomisasi maka dari 87 sampel dibagi menjadi 2 kelompok yaitu sebanyak 44 orang teralokasi ke kelompok A dan sebanyak 43 orang teralokasi ke kelompok B.

Selama penelitian terdapat 3 orang dari kelompok A yang tidak dapat mengikuti penelitian sampai selesai karena mengikuti perjalanan dinas ke luar kota selama 2 minggu, 3 orang tidak mau diambil darahnya, 1 orang sulit ditemui selama penelitian, dan 4 orang gagal diperiksa darahnya karena lisis. Pada kelompok B terdapat 1 orang mundur karena hamil, 4 orang mundur dari penelitian karena mengalami keluhan setelah meminum kapsul, 3 orang gagal diperiksa darahnya karena lisis, dan 2 orang mundur karena mengalami kecelakaan dan mendapat perawatan di rumah sakit. Dengan demikian, sampel yang mengikuti sampai akhir penelitian sebanyak 66 orang dengan rincian 33 orang kelompok $A$ dan 33 orang kelompok B. Variabel bebas berupa pemberian kapsul ekstrak teh hijau sedangkan variabel terikatnya adalah berat badan dan kadar MDA. Variabel pengganggu adalah aktivitas fisik, pemakaian alat kontrasepsi, dan asupan zat gizi sedangkan variabel terkendali adalah umur dan jenis kelamin.

Kelompok perlakuan diberikan ekstrak teh hijau sebanyak $576 \pm 3,3 \mathrm{mg}$ yang mengandung $242,5 \pm 4 \mathrm{mg}$

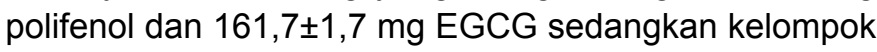
kontrol diberikan tepung jagung sebesar $576 \pm 3,3 \mathrm{mg}$ (8). Data berat badan diperoleh berdasarkan hasil pengukuran menggunakan timbangan digital merk Omron Karada Scan HBF-356. Tinggi badan diukur menggunakan microtoice dengan ketelitian $0,1 \mathrm{~cm}$. Pengukuran berat badan dan tinggi badan dilaksanakan pada awal penelitian, hari ke-30 (minggu ke-4), hari ke-60 (minggu ke-8), dan hari ke-90 (minggu ke-12) yang dilakukan masing-masing sebanyak 3 kali dan diambil rata-rata pengukuran. Pada awal dan akhir penelitian (hari ke-90) dilakukan pengambilan sampel darah untuk menghitung kadar MDA berdasarkan reaksi plasma dengan asam thiobarbiturat. Nilai MDA normal yaitu kurang dari $4 \mathrm{nmol} / \mathrm{ml}$ plasma darah (17).

Asupan zat gizi dikategorikan berdasarkan nilai angka kecukupan gizi (AKG) dari asupan zat gizi yang dikonsumsi. Formulir multiple recall 24 jam selama 6 hari digunakan untuk mencatat jenis dan jumlah makanan yang dikonsumsi dalam ukuran rumah tangga dan ukuran berat dalam gram. Pembagian kapsul dilaksanakan 2 minggu sekali bersamaan dengan recall 24 jam dan pemeriksaan subjek. Pemilihan hari untuk recall 24 jam adalah 4 kali diambil pada hari kerja dan 2 hari diambil pada akhir pekan. Pengambilan data ini dilakukan oleh peneliti dibantu enumerator.

Data aktivitas fisik diperoleh dengan menggunakan kuesioner aktivitas fisik yaitu The International Physical Activity Quetionnaire (IPAQ). Data yang diperoleh dihitung berdasarkan total volume aktivitas fisik yang dinyatakan dalam ekuivalen metabolic energy turnover (MET) dikalikan waktu yang digunakan bagi semua aktivitas dan diklasifikasikan menjadi ringan $\left(2,5-4,4 \mathrm{~mL} \mathrm{O}_{2} / \mathrm{kg}\right.$ per menit) dan berat $\left(6-8,4 \mathrm{~mL} \mathrm{O}_{2} / \mathrm{kg}\right.$ per menit) (18). Alat kontrasepsi dikategorikan hormonal jika berupa pil KB, susuk atau implant, dan suntik KB sedangkan kategori non hormonal jika berupa IUD, steril, dan kondom (19). Uji statistik yang dilakukan antara lain uji Chi-Square dan t-test.

\section{HASIL}

\section{Karakteristik subjek penelitian}

Setelah dilakukan analisis, apoteker menginformasikan bahwa kelompok $A$ adalah subjek yang mengonsumsi kapsul ekstrak teh hijau (perlakuan) dan kelompok B adalah subjek 
Tabel 1. Karakteristik subjek penelitian

\begin{tabular}{|c|c|c|c|}
\hline \multirow[b]{2}{*}{ Variabel } & \multicolumn{2}{|c|}{ Kelompok } & \multirow[b]{2}{*}{$\mathbf{p}$} \\
\hline & $\begin{array}{c}\begin{array}{c}\text { Perlakuan } \\
(n=33)\end{array} \\
\end{array}$ & $\begin{array}{c}\text { Kontrol } \\
(n=33)\end{array}$ & \\
\hline \multicolumn{4}{|l|}{ Umur (tahun) } \\
\hline $35-45$ & $22(67 \%)$ & $17(52 \%)$ & 0,380 \\
\hline $46-55$ & $11(33 \%)$ & $16(48 \%)$ & \\
\hline Berat badan $(\mathrm{kg})$ & $69,4 \pm 11,9$ & $64,4 \pm 8,1$ & 0,138 \\
\hline Tinggi badan $(\mathrm{cm})$ & $154,9 \pm 5,2$ & $151,9 \pm 7,2$ & 0,173 \\
\hline IMT $\left(\mathrm{kg} / \mathrm{m}^{2}\right)$ & $29,1 \pm 3,5$ & $27,9 \pm 5,9$ & 0,284 \\
\hline MDA (nmol/mL) & $8,5 \pm 1,1$ & $8,4 \pm 1,3$ & 0,879 \\
\hline \multicolumn{4}{|l|}{ Aktivitas fisik } \\
\hline Berat & $22(67 \%)$ & $11(15 \%)$ & $0,000^{*}$ \\
\hline Ringan & $11(33 \%)$ & $28(85 \%)$ & \\
\hline \multicolumn{4}{|l|}{ Alat kontrasepsi } \\
\hline Non hormonal & $14(42 \%)$ & $21(64 \%)$ & 0,084 \\
\hline Hormonal & $19(58 \%)$ & $12(36 \%)$ & \\
\hline \multicolumn{4}{|l|}{ Asupan zat gizi } \\
\hline \multicolumn{4}{|l|}{ Energi (KKal) } \\
\hline \multicolumn{4}{|c|}{ (100\% AKG energi) } \\
\hline$\leq 1800$ & $29(88 \%)$ & $29(88 \%)$ & 1,000 \\
\hline$>1800$ & $4(12 \%)$ & $4(12 \%)$ & \\
\hline \multicolumn{4}{|l|}{ Protein (g) } \\
\hline \multicolumn{4}{|c|}{ (10\% AKG energi) } \\
\hline$\leq 31,85$ & $5(15 \%)$ & $6(18 \%)$ & 0,741 \\
\hline$>31,85$ & $28(85 \%)$ & $27(82 \%)$ & \\
\hline \multicolumn{4}{|l|}{ Lemak (g) } \\
\hline \multicolumn{4}{|c|}{ (30\% AKG energi) } \\
\hline$\leq 57,14$ & $28(85 \%)$ & $26(79 \%)$ & 0,523 \\
\hline$>57,14$ & $5(15 \%)$ & $7(21 \%)$ & \\
\hline \multicolumn{4}{|c|}{$\begin{array}{l}\text { Karbohidrat (g) } \\
(60 \% \text { AKG energi) }\end{array}$} \\
\hline$\leq 263$ & $30(91 \%)$ & $28(85 \%)$ & 0,451 \\
\hline$>263$ & $3(9 \%)$ & $5(15 \%)$ & \\
\hline
\end{tabular}

Keterangan : * signifikan $(p<0,05)$; IMT = indeks massa tubuh; MDA = Malondialdehid; $A K G=$ angka kecukupan gizi

Tabel 2. Rerata asupan zat gizi subjek pada kelompok perlakuan dan kontrol

\begin{tabular}{lccc}
\hline \multicolumn{1}{c}{ Variabel } & $\begin{array}{c}\text { Perlakuan } \\
(\bar{X} \pm \text { SD) }\end{array}$ & $\begin{array}{c}\text { Kontrol } \\
(\bar{X} \pm \text { SD })\end{array}$ & $\mathbf{p}$ \\
\hline Energi (Kkal) & $1444 \pm 357$ & $1330 \pm 320$ & 0,646 \\
Protein $(\mathrm{g})$ & $45 \pm 12$ & $44 \pm 13$ & 0,192 \\
Lemak $(\mathrm{g})$ & $44 \pm 14$ & $50 \pm 14$ & 0,182 \\
Karbohidrat $(\mathrm{g})$ & $209 \pm 55$ & $192 \pm 59$ & 0,151 \\
Vitamin C $(\mathrm{mg})$ & $53 \pm 2$ & $50 \pm 3$ & 0,108 \\
Vitamin E $(\mathrm{mg})$ & $0,1 \pm 2$ & $0,1 \pm 2$ & 0,990 \\
Vitamin A $(\mu \mathrm{g})$ & $273 \pm 0,3$ & $272 \pm 0,3$ & 0,576 \\
\hline
\end{tabular}

yang mengonsumsi kapsul plasebo (kontrol). Berdasarkan data karakteristik subjek, terlihat bahwa sebagian besar termasuk dalam kelompok umur 35-45 tahun (59\%) kemudian diikuti umur $46-55$ tahun $(41 \%)$. Berat badan subjek berkisar antara 59-80 kg dan tinggi badan berkisar antara 146-161 cm dengan IMT berkisar antara 24-27 kg/ $\mathrm{m}^{2}$ sedangkan kadar MDA subjek berkisar antara 6-10 nmol/ $\mathrm{mL}$. Sebagian besar subjek penelitian memiliki aktivitas fisik ringan (59\%) dan menggunakan kontrasepsi non hormonal (53\%). Rerata asupan zat gizi subjek penelitian lebih rendah dari AKG yaitu $87 \%$ untuk energi, $81 \%$ untuk lemak, $87 \%$ untuk karbohidrat, dan hanya asupan protein yang lebih tinggi dari AKG yaitu $83 \%$.

Hasil uji Chi Square menunjukkan tidak terdapat perbedaan yang signifikan pada penggunaan kontrasepsi dan asupan zat gizi $(p>0,05)$. Demikian pula uji t-test terhadap rerata berat badan, IMT, dan kadar MDA menunjukkan tidak terdapat perbedaan yang signifikan $(p>0,05)$ sehingga bisa disimpulkan bahwa subjek pada kedua kelompok bersifat homogen. Namun, terdapat satu variabel yang menunjukkan perbedaan yang signifikan $(p<0,05)$ yaitu aktivitas fisik (Tabel 1$)$.

\section{Asupan zat gizi}

Asupan zat gizi diperoleh berdasarkan wawancara menggunakan formulir multiple recall 24 jam sebanyak 6 kali. Pada umumnya pola makan subjek adalah 2-3 kali makan utama dan 1-2 kali makan selingan. Sumber protein hewani dan nabati juga dikonsumsi masing-masing sekitar 1-2 porsi sehari. Hasil uji t-test menunjukkan bahwa perbedaan rerata asupan zat gizi antar kelompok tidak signifikan $(p>0,05)($ Tabel 2$)$.

\section{Efek pemberian ekstrak teh hijau terhadap berat badan dan kadar malondialdehid}

Rerata berat badan subjek pada kelompok perlakuan mengalami penurunan sebesar $1,3 \%$ dibandingkan rerata berat badan pada awal penelitian sedangkan pada kelompok kontrol terjadi kenaikan berat badan sebesar $0,6 \%$ dibandingkan berat badan pada awal penelitian. Perubahan berat badan antara awal dan akhir penelitian serta selisih berat badan berdasarkan kelompok disajikan pada Tabel 3. Hasil uji t-test menunjukkan tidak terdapat perbedaan yang signifikan antara berat badan pada awal penelitian dan setelah 12 minggu perlakuan $(p=0,501)$, demikian juga untuk kelompok kontrol $(p=0,620)$. Selisih perubahan berat badan setelah diuji dengan uji t-test menunjukkan adanya perbedaan yang signifikan antara kelompok perlakuan dan kelompok kontrol $(p=0,000)$.

Kadar MDA pada kelompok perlakuan mengalami penurunan $10 \%$ dibandingkan dengan awal penelitian sedangkan pada kelompok kontrol terjadi penurunan sebesar $8,3 \%$. Hasil penelitian menunjukkan bahwa terdapat perbedaan kadar MDA yang signifikan antara awal penelitian dengan 12 minggu setelah penelitian pada kelompok perlakuan $(p=0,006)$, tetapi tidak demikian dengan kelompok kontrol $(p=0,123)$. Selisih perubahan kadar MDA setelah diuji dengan t-test menunjukkan perbedaan yang tidak signifikan antara kelompok kontrol dan perlakuan $(p=0,278)$. 
Tabel 3. Perubahan rerata berat badan dan kadar MDA setelah perlakuan selama 12 minggu

\begin{tabular}{lccccc}
\hline Variabel & $\begin{array}{c}\text { Awal penelitian } \\
(\mathbf{x} \pm \mathbf{S D})\end{array}$ & $\begin{array}{c}\text { Akhir penelitian } \\
(\mathbf{x} \pm \mathbf{S D})\end{array}$ & $\mathbf{p}$ & $\begin{array}{c}\text { Perubahan } \\
(\mathbf{\Delta x \pm S D )}\end{array}$ & $\mathbf{p}$ \\
\hline Berat badan & & & & & \\
Perlakuan & $69,4 \pm 11,9$ & $68,9 \pm 11,7$ & 0,501 & $-0,5 \pm 1,8$ & 0,000 \\
Kontrol & $64,4 \pm 8,1$ & $64,9 \pm 8,2$ & 0,620 & $0,5 \pm 1,0$ & \\
Kadar MDA & & & & & \\
Perlakuan & $8,5 \pm 1,2$ & $7,4 \pm 1,1$ & 0,123 & $-1,1 \pm 0,1$ & 0,278 \\
Kontrol & $8,4 \pm 1,3$ & $7,6 \pm 1,2$ & 0,278 & $-0,8 \pm 0,03$ & \\
\hline
\end{tabular}

\section{BAHASAN}

\section{Karakteristik subjek penelitian}

Hasil penelitian menunjukkan tidak terdapat perbedaan yang signifikan pada karakteristik subjek kecuali pada aktivitas fisik sehingga dapat dikatakan subjek penelitian homogen. Pada kelompok perlakuan, lebih banyak subjek (67\%) yang mempunyai aktivitas berat dibandingkan kelompok kontrol (15\%) dan berdasarkan hasil analisis menunjukkan adanya perbedaan yang signifikan $(p<0,05)$.

Kepatuhan subjek dalam mengonsumsi kapsul ekstrak teh hijau maupun kapsul plasebo dalam penelitian ini diketahui melalui wawancara setiap dua minggu sekali bersamaan dengan distribusi kapsul ekstrak teh hijau dan kapsul plasebo. Rerata jumlah kapsul ekstrak teh hijau yang dikonsumsi selama 90 hari adalah 73 kapsul atau $81 \%$ sehingga rerata jumlah kapsul yang tidak dikonsumsi sebanyak 17 kapsul. Hal ini karena subjek lupa mengonsumsi ataupun hilang. Namun demikian, pencapaian tersebut dianggap sudah cukup baik karena telah mencapai lebih dari $80 \%$.

\section{Asupan zat gizi}

Asupan zat gizi berdasarkan hasil recall 24 jam sebanyak 3 kali pada awal penelitian secara statistik menunjukkan tidak terdapat perbedaan yang signifikan antara perlakuan dan kontrol. Dengan demikian, diharapkan perubahan yang terjadi pada subjek setelah 12 minggu penelitian bukan karena perbedaan jumlah asupan zat gizi antara perlakuan dan kontrol melainkan disebabkan efek dari ekstrak teh hijau. Hal ini didukung pula oleh data recall sebanyak 3 kali yang dilakukan selama penelitian bahwa rata-rata asupan zat gizi baik energi, protein, lemak, karbohidrat, vitamin $\mathrm{C}$, vitamin $\mathrm{E}$, dan vitamin $\mathrm{A}$ pada awal penelitian tidak berbeda signifikan dengan rata-rata asupan zat gizi pada akhir penelitian.

Hasil penelitian menunjukkan bahwa sebagian besar subjek penelitian memiliki rerata asupan zat gizi di bawah nilai AKG dan tidak terdapat perbedaan yang signifikan antara kelompok kontrol dan perlakuan. Kelebihan berat badan pada subjek bisa terjadi karena aktivitas fisik yang rendah sehingga asupan zat gizi yang masuk ke dalam tubuh tidak diubah menjadi energi melainkan tersimpan sebagai lemak di dalam tubuh. Hal lain yang menyebabkan terjadinya kelebihan berat badan pada subjek penelitian adalah ketidakjujuran dari subjek penelitian dalam menyampaikan informasi saat dilakukan recall. Hal ini menjadi kelemahan dalam penelitian ini di mana kejujuran subjek sulit dibuktikan walaupun sudah diminimalisir dengan melakukan multiple recall.

\section{Efek pemberian ekstrak teh hijau terhadap berat badan}

Hasil penelitian menunjukkan terjadinya penurunan berat badan pada kelompok perlakuan setelah mengonsumsi ekstrak teh hijau namun tidak signifikan. Penurunan berat badan terjadi karena katekin dalam teh menghambat aktivitas catechol-O-methyltransferase yaitu enzim yang mempercepat penurunan katekolamin termasuk epinefrin dan norepinefrin. Penghambatan enzim ini menyebabkan terjadinya peningkatan aktivitas sistem saraf simpatik yang diikuti peningkatan sekresi hormon epinefrin, norepinefrin, glukagon, adrenocorticotropin hormone (ACTH), thyroidstimulating hormone (TSH), growth hormone $(\mathrm{GH})$, dan vasopresin yang berdampak peningkatan lipolisis. Peningkatan lipolisis akan diikuti dengan peningkatan termogenesis dan oksidasi asam lemak, dengan adanya peningkatan oksidasi asam lemak maka semakin banyak asetil-KoA yang dibentuk. Peningkatan termogenesis akan menyebabkan peningkatan oksidasi asetil-KoA melalui siklus asam sitrat yang dilanjutkan dengan tahap fosforilasi oksidatif untuk menghasilkan energi $(20,21)$.

Peningkatan termogenesis berdampak pula pada penurunan terjadinya lipogenesis dan esterifikasi sehingga semakin sedikit asetil-KoA yang diubah menjadi triasilgliserol yang merupakan simpanan lemak di jaringan adiposa. Jika dilihat dari asupan zat gizi, rata-rata subjek penelitian mempunyai asupan zat gizi di bawah nilai AKG kecuali protein. Oleh karena itu, tubuh menggunakan simpanan lemak (triasilgliserol) sebagai sumber energi melalui oksidasi lemak. Dengan meningkatnya oksidasi lemak maka simpanan lemak menurun, hal ini berimplikasi pada penurunan berat badan. Kondisi ini didukung pula oleh penelitian yang merupakan bagian dari penelitian ini yang juga dilakukan di lingkungan Dinas Kesehatan Kota Yogyakarta pada subjek wanita overweight (22). Penelitian tersebut menunjukkan bahwa terjadi penurunan yang signifikan pada total lemak tubuh (TLT) subjek, kadar kolesterol, dan kadar low density lipoprotein (LDL). Kadar 
high density lipoprotein (HDL) mengalami peningkatan sedangkan kadar trigliserida mengalami penurunan, namun keduanya tidak signifikan.

Penelitian ini menunjukkan hasil yang berbeda dengan penelitian yang dilakukan di Kao Corporation, Tokyo. Penelitian tersebut menunjukkan penurunan berat badan yang signifikan pada subjek laki-laki yang diberikan ekstrak teh hijau (12). Hal ini mungkin karena adanya perbedaan subjek penelitian yaitu metabolisme laki-laki lebih tinggi 5\% hingga 10\% dibandingkan wanita pada berat badan dan tinggi badan yang sama. Semakin tinggi metabolisme seseorang maka semakin mudah menurunkan berat badannya (23). Metabolisme tubuh pada wanita berjalan lebih lambat daripada pada laki-laki. Selain itu, kemungkinan juga disebabkan oleh faktor endokrin yang berubah pada wanita yang sudah mengalami menopause. Kemungkinan yang lain adalah pada penelitian ini tidak dilakukan karantina terhadap subjek sehingga asupan makan subjek tidak dapat dikontrol sedangkan pada penelitian yang dilakukan di Tokyo, Jepang (24) dilakukan karantina sehingga asupan zat gizi yang dikonsumsi benar-benar dapat dikontrol. Sementara itu, jumlah ekstrak teh hijau yang digunakan juga berbeda yaitu pada penelitian di Tokyo menggunakan ekstrak teh hijau dengan kadar katekin 690 mg sedangkan pada penelitian ini menggunakan ekstrak teh hijau dengan kadar katekin $242,5 \pm 4 \mathrm{mg}$ sehingga terjadi perbedaan hasil penelitian.

Penurunan berat badan yang tidak signifikan pada penelitian ini disebabkan adanya pengaruh aktivitas fisik pada subjek penelitian yang cenderung ringan sehingga termogenesis tidak berjalan cepat. Kondisi ini menjadi kelemahan dalam penelitian ini karena hasil penelitian bisa dipengaruhi aktivitas fisik. Hasil penelitian yang dilakukan di Geneva (25) membuktikan bahwa peningkatan termogenesis dan oksidasi lemak secara signifikan terjadi pada subjek yang mengonsumsi ekstrak teh hijau dan melakukan aktivitas fisik secara intensif. Hal ini didukung oleh penelitian di Netherlands (23) yang menunjukkan bahwa konsumsi katekin teh menginduksi reduksi berat badan dan lemak tubuh serta meningkatkan energy expenditure. Berdasarkan penelitian di Birmingham, UK (26) menyebutkan bahwa pemberian ekstrak teh hijau selama latihan intensitas sedang menyebabkan peningkatan oksidasi lemak dibandingkan selama istirahat atau tanpa latihan. Dengan demikian, dapat disimpulkan bahwa dengan meningkatnya aktivitas seseorang maka energy expenditure yang dihasilkan juga akan meningkat.

Hasil penelitian ini menunjukkan hasil yang tidak signifikan, hal ini dapat terjadi kemungkinan karena asupan zat gizi subjek tidak dikontrol selama penelitian, walaupun secara statistik asupan zat gizi antara kelompok kontrol dan perlakuan tidak berbeda signifikan. Selain itu, aktivitas fisik subjek juga tidak homogen sehingga dapat mempengaruhi hasil penelitian, walaupun secara statistik aktivitas fisik bukan faktor pengganggu. Kemungkinan yang lain adalah penggunaan alat kontrasepsi hormonal. Penggunaan alat kontrasepsi yang mengandung hormon estrogen dan progesteron menyebabkan gangguan metabolisme karbohidrat, lemak, dan lipoprotein yang berakibat kegemukan.

\section{Efek pemberian ekstrak teh hijau terhadap kadar malondialdehid}

Hasil penelitian menunjukkan bahwa terdapat perbedaan kadar MDA yang signifikan antara awal penelitian dengan 12 minggu setelah penelitian pada kelompok perlakuan $(p=0,006)$. Hal ini terjadi karena ekstrak teh hijau mengandung polifenol yang merupakan antioksidan non-enzimatis atau antioksidan sekunder. Antioksidan ini bekerja dengan cara memotong reaksi oksidasi berantai dari radikal bebas atau dengan cara menangkapnya (17).

Kondisi ini didukung oleh hasil penelitian di Tokyo, Jepang (27) yang menyatakan bahwa gugus hidroksi fenolik yang terdapat dalam teh hijau mempunyai peran penting sebagai antioksidan melalui penangkapan radikal hidroksi. Selain itu, kemungkinan lain adalah adanya myrcetin dan quercetin (golongan falavanol) dalam teh yang mempunyai kemampuan menjaga dan meregenerasi a-tokoferol (28). a-tokoferol merupakan antioksidan yang mampu mempertahankan integritas membran. a-tokoferol bekerja sebagai donor ion hidrogen yang mampu mengubah radikal peroksil (hasil peroksidasi lipid) menjadi radikal tokoferol yang kurang reaktif sehingga tidak mampu merusak rantai asam lemak (17). Selain itu, a-tokoferol juga berfungsi menurunkan kadar kolesterol LDL serum dan menghambat oksidasi kolesterol LDL (29). Ekstrak teh hijau juga mengandung mineral zink (Zn), mangan $(\mathrm{Mn})$, tembaga $(\mathrm{Cu})$, dan selenium (Se) yang merupakan komponen antioksidan primer (superoksida dismutase dan glutation peroksidase) (30). Pencegahan pembentukan radikal bebas baik pada awal pembentukan radikal bebas maupun pada peroksidasi lipid akan menyebabkan terjadinya penurunan kadar MDA dalam darah yang merupakan hasil akhir dari peroksidasi lipid.

Penurunan kadar MDA pada kelompok perlakuan menunjukkan hasil yang tidak signifikan jika dibandingkan dengan penurunan pada kelompok kontrol. Hal ini mungkin karena asupan vitamin antioksidan yang masih kurang yaitu terlihat dari rerata asupan vitamin $\mathrm{C}$, vitamin $\mathrm{E}$, dan vitamin A yang masih di bawah AKG. Vitamin-vitamin tersebut berfungsi sebagai pemutus reaksi pembentukan radikal bebas sehingga tidak terbentuk radikal bebas baru. Selain itu, penurunan kadar MDA yang tidak signifikan dapat terjadi karena subjek penelitian yang tidak dikarantina 
sehingga kemungkinan subjek mengonsumsi makanan yang tinggi lemak dan karbohidrat. Hal ini terlihat dari kadar MDA awal yang jauh lebih tinggi dari normal (nilai MDA normal yaitu kurang dari $4 \mathrm{nmol} / \mathrm{ml}$ plasma darah). $\mathrm{Hal}$ ini berbeda dengan penelitian yang menunjukkan adanya penurunan kadar MDA yang signifikan pada tikus yang diberi ekstrak teh hijau yang ditambahkan pada ransum sebanyak $10 \mathrm{~g} / \mathrm{kg}$ ransum (14). Perbedaan hasil penelitian ini terjadi karena pada penelitian tersebut menggunakan hewan coba yaitu tikus sedangkan pada penelitian ini menggunakan manusia. Tikus mempunyai kemampuan untuk mensintesis vitamin $C$ sendiri sehingga mampu memenuhi kebutuhan vitamin antioksidan dalam tubuhnya. Berbeda dengan manusia yang tidak mampu mensintesis sendiri sehingga sangat tergantung pada asupan vitamin $\mathrm{C}$.

\section{SIMPULAN DAN SARAN}

Berdasarkan hasil penelitian ini dapat disimpulkan bahwa pemberian ekstrak teh hijau dapat menurunkan berat badan lebih dan kadar malondialdehid dalam darah wanita dewasa di lingkungan pegawai Dinas Kesehatan Kota Yogyakarta namun penurunan tersebut tidak signifikan. Penelitian lanjutan dengan melakukan karantina terhadap subjek dan pengujian sampai berapa lama konsumsi ekstrak teh hijau dapat dikonsumsi secara teratur perlu dilakukan sehingga dapat diketahui efek pemberian ekstrak teh hijau terhadap perubahan berat badan dan kadar malondialdehid yang signifikan.

\section{RUJUKAN}

1. Misnadiarly. Obesitas sebagai faktor risiko beberapa penyakit. Jakarta: Pustaka Obor Populer; 2007.

2. Badan Penelitian Pengembangan Kesehatan. Laporan hasil riset kesehatan dasar (Riskesdas) Indonesia tahun 2010. Jakarta: Departemen Kesehatan Republik Indonesia; 2011.

3. Adiningsih S. Indonesia nutritional pattern in contributing prevalence of obesity. Fight obesity from cells to community. Malang: Laboratorium IImu Faal FK UNIBRAW; 2006.

4. Cabrera C, Artacho R, Gimenez R. Benefical effect of green tea. J Am Coll Nutr 2006;25(2):79-99.

5. Dewi K. Pengaruh ekstrak teh hijau (Camellia sinensis var. Assamica) terhadap penurunan berat badan, kadar trigliserida dan kolesterol total pada tikus jantan Galur Wistar. JKM 2008;7(2):156-63.

6. Toruon PL, Lukman G, Bony O. Performance nutrition. Jakarta: Prima Diet Catering; 2008.

7. Chu DC, Juneja LR. General chemical composition of green tea and its infusion. Chemistry and applications of green tea. New York: CRC Press New York; 1997.
8. Gunawiyaya FA. Penentuan LD-50 ekstrak teh hijau pada mencit strain $\mathrm{C} 3 \mathrm{H}$. Majalah IImu Kedokteran USAKTI 1996;15(4):1645-50.

9. Yang CS, Landau JM. Effect of tea consumption on nutrition and health. J Nutr 2000;130(10):2409-12.

10. Westerterp-Plantega MS, Lejeune MP, Kovacs EM. Body weight loss and weight maintenance in relation to habitual caffeine intake and green tea supplementation. Obes Res 2005;13(7):1195-204.

11. Naim R. Manfaat teh hijau bagi kesehatan. Jurnal Medika 2003;4:243-5.

12. Nagao $T$, Komine $Y$, Soga $S$, Meguro $S$, Hase $T$, Tanaka $Y$, Tokimitsu I. Ingestion of a tea rich in catechins leads to a reduction in body fat and malondialdehyde-modified LDL in men. Am J Clin Nutr 2005;81(1):122-9.

13. Onge MP. Dietary fats, teas, dairy, and nuts: potensial functional foods for weight control. Am J Clin Nutr 2005;81(1):7-15.

14. Hartoyo A, Mary A. Aktivitas antioksidatif dan hipokolesterolemik ekstrak teh hijau dan teh wangi pada tikus yang diberi ransum kaya asam lemak tidak jenuh ganda. Jurnal Teknologi dan Industri Pangan 2002;8(1):78-85.

15. Lemeshow S, Hosmer Jr DW, Klar J, Lwanga SK. Adequacy of sample size in health studies. Toronto: Willey \& Sons; 1990.

16. WHO. Appropriate body-mass index for Asian populations and its implications for policy and intervention strategies. Lancet 2004;363(9412):15763.

17. Winarsi H. Antioksidan alami dan radikal bebas: potensi dan aplikasinya dalam kesehatan. Yogyakarta: Kanisius; 2007.

18. Gibney MJ, Margetts GM, Kearney JM, Arab L. Gizi kesehatan masyarakat. Jakarta: EGC; 2008.

19. Chis $B$. Ensiklopedia keperawatan (churchillivingstones mini encyclopaedia of nursing $1^{\text {st }}$ ed). Jakarta: EGC; 2005.

20. Shils ME, Moshe S, Catharine R, Benjamin, Robert JC. Modern nutrition in health and disease. 10 ed. London: Lippincott Williams \& Wilkins; 2006.

21. Murray RK, Granner DK, Mayes PA, Rodwell VW. Biokimia harper (Harper's Illustrated Biochemistry). 27 ed. Jakarta: Penerbit buku kedokteran EGC; 2006.

22. Hardani E. Efek pemberian ekstrak teh hijau (Camelia sinensis (L.)O Kuntze) var. assamica terhadap total lemak tubuh dan profil lipid wanita dewasa overweight di lingkungan pegawai Dinas Kesehatan Kota Yogyakarta [Tesis]. Yogyakarta: Universitas Gadjah Mada; 2011.

23. Diepvens K, Westerterp KR, Westerterp-Plantega MS. Obesity and thermogenesis related to the consumtion of caffein, ephedrine, capsaicin, and green tea. Am J Physiol Regul Integr Comp Physiol 2007;292(1):R77-85. 
24. Nagao T, Komine $Y$, Soga S, Meguro S, Hase T, Tanaka Y, Tokimitsu I. Ingestion of a tea rich in catechins leads to a reduction in body fat and malondialdehyde-modified LDL in men. Am J Clin Nutr 2005;81(1):122-9.

25. Dullo AG, Durret $C$, Rohrer D, Giardier L, Mensi N, Fathi $M$, Chantre P, Vandermander J. Efficacy of a green tea extract rich in catechin polyphenols and caffeine in increasing 24-h energy expenditure and fat oxidation in humans. Am J Clin Nutr 1999;70(6):1040-5.

26. Venables MC, Hulston CJ, Cox HR, Jeukendrup AE. Green tea extract ingestion, fat oxidation, and glucose tolerance in healthy humans. Am J Clin Nutr 2008;87(3):778-84.
27. Koketsu M. Antioxidative activity of tea polyphenols. In: Takehiko Y, Lekh RJ, Djoing CC, Mujo K. Chemistry and applications of green tea. New York: CRC Press New York; 1997.

28. Zhu QY, Huang Y, Chen ZY. Interaction between flavonoids and alpha-tocopherol in human low density lipoprotein. J Nutr Biochem 2000;11(1):14-21.

29. Soliman GZA. Blood lipid peroxidation (superoxide dismutase, malondialdehyde, glutathion) level in egyption type 2 diabetic patients. Singapore Med J 2008;49(2):129-36.

30. Metzler DE. Biochemistry the chemical reactions of living cells. New York: Academic Press.Inc; 1977. 